\title{
MATHEMATICAL MODELS FOR EXTRACTING PILE FROM THE SOIL WITH THE HELP OF MULTIBARRELED ARTILLERY SYSTEMS
}

\author{
O. G. Pensky ${ }^{1}$, ogpensky@mail.ru,
}

A. G. Kuznetsov ${ }^{1}$, sp_9914@mail.ru.

${ }^{1}$ Perm State National Research University, Perm, Russian Federation.

\begin{abstract}
The article describes a method for extracting piles from the soil using the multibarreled artillery recoiling systems. The method is based on the recoil of guns during a shot and the rigid connection between the extracted pile and the recoiling parts of the guns. In order to describe the extraction of piles from the soil, we consider a tubular chopped powder. We propose mathematical models to calculate the dynamics of guns during a simultaneous shot from all the barrels and determine the amount of extraction of pile from the soil. The paper describes a technique for performing the necessary calculations, which is based on a phased solution of the Cauchy problem for the first and second shot periods. Numerical experiment shows the principal possibility to use the existing single-barreled building artillery systems to extract piles from the soil. For modelling calculations of extracting piles from the soil, we use parameters of the installation for the shooting of anchors and piles, which is introduced into the industry for the oil and gas field building.
\end{abstract}

Keywords: mathematical models; building; artillery guns; dynamics; penetration.

\section{Introduction}

The urban planning often set the problem of eliminating the so-called long-term building. One of the types of work performed for the eliminating is the extraction of piles from the soil. Many of the existing methods that solve this problem are difficult to apply for point building.

Fig. 1 and Fig. 2 shows a diagram of the multibarreled recoiling artillery system that allows to extract piles from the soil due to the energy of the recoil of guns during their simultaneous shot [1].

The method of extracting building elements from the soil with the help of multibarreled artillery guns includes the following sequence of operations:

- set stamps 6 in the barrels of artillery guns 2 ;

- take a platform 3 in the form of a circle with points of contact at the ends of the circle diameter and install the platform on breech ends of artillery guns 4 such that each pair of recoiling pieces of the artillery guns are on opposite ends of diameters of the platform 3 ;

- attach the center of the circle of the platform 3 to the head of the extracted building element 7 by the tensioned cable 5 ;

- produce a synchronized shot from all guns;

- the platform 3 rises up due to recoil during the shot and extracts the building element 7 from the soil 1. 




Fig. 1. Diagram of the extracting piles from the soil with the help of multibarreled recoiling artillery guns (side view)

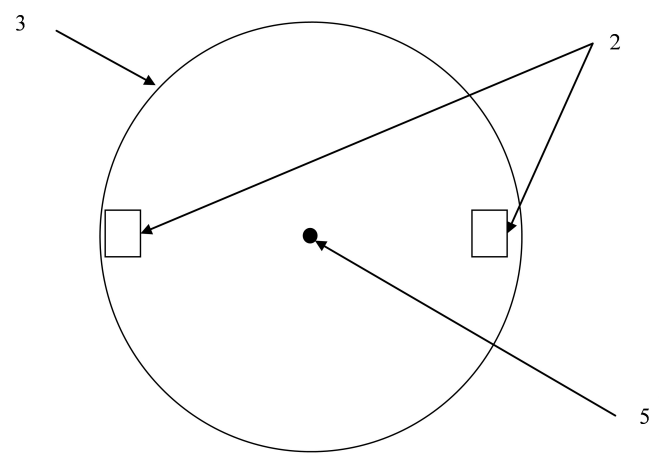

Fig. 2. Diagram of the extracting piles from the soil with the help of multibarreled recoiling artillery guns (top view)

Let us describe a mathematical model for extracting piles from the soil by the recoiling parts of multibarreled guns with the same technical characteristics and conditions of charging for each of guns of the artillery system.

\section{Mathematical Model}

In order to develop a mathematical model, we consider the thermodynamic theory of shot within the assumptions $[2,3]$ that we use tubular chopped powder.

The preliminary shot period for each of the guns is described by the following wellknown formula:

$$
\Psi_{0}=\frac{\frac{1}{\Delta}-\frac{1}{\delta}}{\frac{f}{p_{0}}+\alpha-\frac{1}{\delta}},
$$

where $\Delta$ is a charge density, $\delta$ is a density of the powder, $f$ is a strength of the powder, $p_{0}$ is a pressure of the forcing of the stamp, $\alpha$ is a covolume of the powder gases. 
We assume that stamps rest the soil before the shot.

In order to analyze the process of shot during the shooting of stamps in the soil, it is necessary to take into account not only some of the energy of the powder gases, which turns into kinetic energy of the translational movement of the building element, but also the energy expended for the performance of another type of work. Therefore, the balance of energy during the shot is complete $[4,5]$.

Let $n$ be a number of guns in a multibarreled system.

Define the work on overcoming the resistance force of the soil to the movement of stamps in the soil, performed due to the energy of the powder gases.

Let $v_{a}$ be an absolute speed of a stamp, $l_{a}$ be an absolute path of the stamp on the gun channel. In this notation, the resistance force of the soil $F$ can be written as

$$
F=F\left(v_{a}, L_{a}\right)
$$

Then the energy necessary for shooting of the stamps on the depth $L_{a}$, if the number of the stamps is equal to $n$, can be written in the form

$$
Z_{1}=n \int_{0}^{L_{a}} F\left(v_{a}, x\right) d x
$$

where $\frac{d x}{d t}=v_{a}$.

Therefore, $Z_{1}$ takes the form

$$
Z_{1}=n \int_{0}^{L_{a}} F\left(v_{a}, x\right) d x
$$

where $\frac{d x}{d t}=l_{a}$.

It is obvious that the kinetic energy of the stamps having mass $m$ at time $t$ satisfies the relation

$$
Z_{2}=n \frac{m v_{a}^{2}}{2}
$$

Recall that the guns of the artillery system are placed vertically and such that the stamps move down during the shot. Therefore, it is obvious that the energy of the powder gases is used to move up the guns and piles. Hence, the performed work can be expressed by the relation

$$
Z_{3}=\left(n Q+q_{c}\right) L_{p}
$$

where $Q$ is a weight of the recoiling parts (barrels) of each artillery guns of the multibarrel artillery system, $q_{c}$ is a weight of the extracted pile, $L_{p}$ is a movement of the recoiling parts.

Moreover, energy of the powder gases gives a speed $V$ to the recoiling parts of the artillery gun and the extracted pile. Consequently, the kinetic energy of the recoiling parts satisfies the following equality:

$$
Z_{4}=\frac{\left(n M+m_{c}\right) V^{2}}{2},
$$


where $M$ is a mass of the recoiling parts of a gun, $m_{c}$ is a mass of the pile.

The energy, which is spent on overcoming the resistance force of the recoil, has the form

$$
Z_{5}=\int_{0}^{L_{p}}\left[n G\left(V, l_{p}\right)+F_{t r}\right] d l_{p},
$$

where $L_{p}$ is a path of the recoil, $G\left(V, l_{p}\right)$ is a resistance force of the recoil, $F_{t r}$ is a frictional force of the side surface of the extracted pile on the soil.

Since the stamps move vertically down, the force of gravity performs the work

$$
Z_{6}=n q L_{a}
$$

which is not performed due to the energy of the powder gases.

Let $E$ be an energy of the powder gases, due to which works $Z_{1}, Z_{2}, Z_{3}, Z_{4}, Z_{5}$ are performed. Then the following relation is obvious:

$$
E=\sum_{i=1}^{5} Z_{i}-Z_{6}
$$

The value $E$ can be approximated in the following form:

$$
E=n\left[\frac{f}{\theta} \omega \Psi-\frac{p\left(W_{\Psi}+s L\right)}{\theta}\right],
$$

where $\theta$ is an adiabatic coefficient of the powder gases without unity, $\omega$ is a mass of the charge in each barrel, $\Psi$ is a relative part of the burned charge in each barrel, $P$ is a pressure in the barrel channels, $W_{\Psi}$ is a free volume of the chamber in each barrel at the moment of combustion of a part of the charge $\Psi, s$ is a cross-section of the channel of each barrel, $L$ is a stamp path along the channel of each barrel.

Replacing the values $Z_{i}$ in the relation (2) by their algebraic expressions and taking into account the formula (3), we obtain the following equality

$$
\begin{gathered}
n\left[\frac{f}{\theta} \omega \Psi-\frac{p\left(W_{\Psi}+s L\right)}{\theta}\right]= \\
=n \int_{0}^{L_{a}} F\left(v_{a}, x\right) d x+n \frac{m v_{a}^{2}}{2}+\left(n Q+q_{c}\right) L_{p}+\frac{\left(n M+m_{c}\right) V^{2}}{2}-n q L_{a}+ \\
+\int_{0}^{L_{p}}\left[n G\left(V, l_{p}\right)+F_{t r}\right] d l_{p} .
\end{gathered}
$$

In the equation (4), we differentiate the parameter $p$ of the pressure in the barrel channel with respect to time $t$ and obtain the relation

$$
\begin{aligned}
& \frac{d p}{d t}=\frac{n \frac{f}{\theta} \omega \frac{d \Psi}{d t}-n v_{a} F\left(v_{a}, L_{a}\right)-n m v_{a} \frac{d v_{a}}{d t}-n Q \frac{d L_{p}}{d t}-q_{c} \frac{d L_{p}}{d t}}{n \frac{W_{\Psi}+s L}{\theta}}- \\
& -\frac{\left(n M+m_{c}\right) V \frac{d V}{d t}+V\left[n G\left(V, L_{p}\right)+F_{t r}\right]+\frac{n p\left(\frac{d W_{\Psi}}{d t}+s v_{a}+s V\right)}{\theta}}{n \frac{W_{\Psi}+s L}{\theta}} .
\end{aligned}
$$


The following obvious equations describe translational motion of the stamp, recoiling parts of the gun and extracted pile:

$$
\begin{gathered}
m \frac{d v_{a}}{d t}=p s-F\left(v_{a}, L_{a}\right)+q, \\
\frac{d L_{a}}{d t}=v_{a} \\
\left(n M+m_{c}\right) \frac{d V}{d t}=n p s-n G\left(V, L_{p}\right)-F_{t r}-Q-q_{c} \\
\frac{d L_{p}}{d t}=V .
\end{gathered}
$$

According to the law of combustion of a tubular chopped powder [3], the following relations are valid:

$$
\begin{aligned}
& \frac{d \Psi}{d t}=p, \frac{d L_{\Psi}}{d t}=-a_{1} p, \\
& a_{1}=\frac{W_{0}}{s}\left(\alpha-\frac{1}{\delta}\right),=\frac{1}{I_{p}},
\end{aligned}
$$

where $I_{p}$ is the total impulse of the pressure of powder gases during the powder combustion.

The initial conditions for solving the system of differential equations (5) - (10) take the form:

$$
p_{/ t=0}=p_{0}, v_{a / t=0}=0, V_{/ t=0}=0, \Psi_{/ t=0}=\Psi_{0}, L_{a / t=0}=0, L_{p / t=0}=0 .
$$

According to the thermodynamic theory of shot, the Cauchy problem [6] describes the first shot period [2].

The equations (5) - (9) of the second shot period [4] are equivalent to the equations of the first shot period, if $\Psi \equiv 1$. The system of differential equations does not include the equation

$$
\frac{d \Psi}{d t}=p
$$

The initial conditions for solving the system of ordinary differential equations for the second shot period are equal to the finite values of the unknown functions of the Cauchy problem describing the first shot period.

\section{Numerical Experiments}

Fig. 3 shows a single-barreled artillery system $(n=1)$ for the shooting of anchors and piles in the soil UZAS-2 [7], which was established in Perm. In order to extract piles from the soil, we can use the system as follows. A stamp with a large area of the mid-section of the base is placed in the barrel. A head of the pile extracted from the soil is rigidly attached to the recoiling parts of the gun. During the shot, the stamp shallow gets into the soil, and the recoiling parts of the gun rise up and extract the pile from the soil. Let us perform calculations of modeling the dynamics of extracting pile from the soil with the help of UZAS-2. 


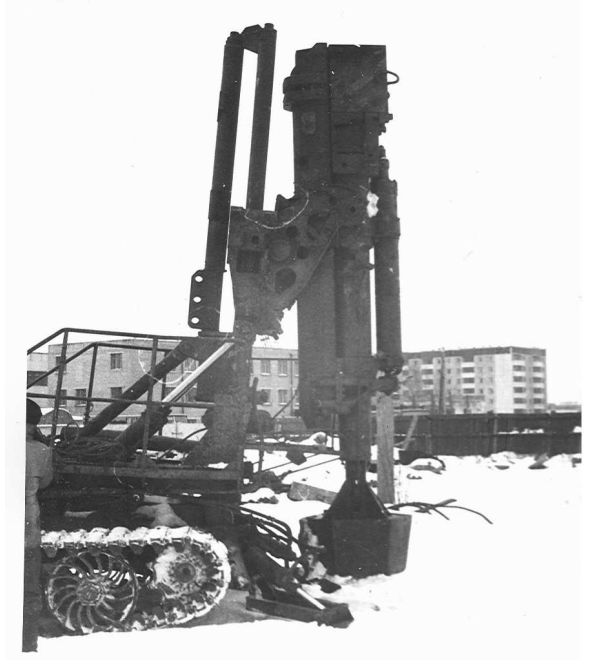

Fig. 3. System UZAS-2 with a stamp getting into the soil

Consider the clay soil with a consistency 0.3 .

The resistance force of the soil $(\mathrm{H})$ to penetration of the stamp is determined by the following relation [2]:

$$
F=F\left(v_{a}, L_{a}\right)=3422 v_{a}^{2} s_{s}+2000000 s_{s}+35000 \pi d_{s} L_{a},
$$

where $s_{s}, d_{s}$ are midsection area and diameter of each stamp, $m$.

The forces $G\left(V, L_{p}\right)$ and $F_{t r}$ satisfy the equalities $(\mathrm{H})$

$$
G\left(V, L_{p}\right)=0, F_{t r}=35000 \pi d_{c}\left(H_{c}-L_{p}\right)
$$

where $H_{c}$ is an initial penetration of the extracted pile.

In order to numerically solve the problem of the shot dynamics, we take the following characteristics of the gun [7], charging conditions, parameters of the stamp and extracted pile: length of the barrel chanel is $1.8 \mathrm{~m}$, weight of the charge is $3 \mathrm{~N}$, barrel caliber is $0.170 \mathrm{~m}$, chamber volume is $0.001026 \mathrm{~m}^{3}$, powder force is $950000 \mathrm{~J} / \mathrm{kg}$, powder density is $1600 \mathrm{~kg} / \mathrm{m}^{3}$, adiabatic index of powder gases is 1.2 , covolume of the powder gases is $0.98 \cdot 10^{-3} \mathrm{~m}^{3} / \mathrm{kg}$, total impulse of gases pressure during the combustion of powder (powder impulse) is $376.500 \mathrm{~Pa} \cdot \mathrm{s}$, weight of the recoiling parts of the gun is $36000 \mathrm{~N}$, diameter of the stamp head is $0.5 \mathrm{~m}$, mass of the stamp is $800 \mathrm{~kg}$, diameter of the extracted pile is $0.168 \mathrm{~m}$, weight of the pile is $240 \mathrm{~kg}$, initial penetration of the pile is $4 \mathrm{~m}$.

In order to calculate dynamics of the gun, we develop a special program [8]. In order to solve the Cauchy problems, we use the Runge-Kutta method of the second order with an integration step $10^{-6} s[2,3]$.

Calculations shows the following dynamic indicators at the end of the shot: maximum pressure in the barrel channel is $654 M P a$, muzzle pressure of the powder gases is 4.2 $M P a$, penetration of the stamp in the soil is $1.13 \mathrm{~m}$, size of the extraction of the pile from the soil is $3.46 \mathrm{~m}$. 


\section{Conclusion}

Therefore, due to the constructed mathematical model and numerical calculations, we show the principal possibility to use recoiling artillery guns for extracting piles from the soil.

\section{References}

1. Pensky O.G., Mazeina N.N., Shestakov E.S. Method of Extraction of Construction Elements from the Soil with the Help of Multibarrelled Artillery Pieces. The Patent Application of the Russian Federation on an Invention no. 2017126845, date of a priority 2017-07-25. (in Russian).

2. Malanin V.V., Ostapenko E.N., Pensky O.G., Chernikov A.V. Schematic Diagrams and Mathematical Models of Construction Artillery Guns. Perm, Perm State University Publ., 2016. (in Russian).

3. Rusyak I.G., Ushakov V.M. Intrachamber Heterogeneous Processes in Barrel Systems. Ekaterinburg, UrO RAN Publ., 2001. (in Russian).

4. Homenko Yu.P., Ishchenko A.N., Kasimov V.Z. Mathematical Modelling of Interior Ballistic Processes in Barrel Systems. Novosibirsk, Publishing House of Siberian Branch of the Russian Academy of Sciences, 1999. (in Russian).

5. Churbanov E.V. Internal Ballistics of an Artillery Piece. Moscow, Voyenizdat Publ., 1973. (in Russian).

6. Tikhonov A.N., Vasilyeva A.B., Sveshnikov A.G. Differential Equations. Moscow, Nauka Publ., 1980. (in Russian).

7. Bartolomey A.A., Grigoriev V.N., Omel'cha I.M., Pensky O.G. Bases of Pulse Technology of the Device of the Bases. Perm, Publishing House of Perm State Technical University, 2002. (in Russian).

8. Pensky O.G. The Program of Calculation of Dynamics for Extracting Pile from the Soil with the Help of Multibarrelled Artillery Systems. Official Bulletin of Computer Programs of Rospatent, Moscow, FIPS, 2017, no. 2017660043, issued 2017-09-13. (in Russian).

Oleg G. Pensky, DSc (Techn), Associate Professor, Department of Mechanics and Mathematical Modelling, Perm State National Research University (Perm, Russian Federation), ogpensky@mail.ru.

Andrei G. Kuznetsov, PhD (Techn), Dean of the Faculty of Mechanics and Mathematics, Perm State National Research University (Perm, Russian Federation), sp_9914@mail.ru.

Received January 25, 2018. 


\title{
МАТЕМАТИЧЕСКИЕ МОДЕЛИ ИЗВЛЕЧЕНИЯ СВАЙ ИЗ ГРУНТА С ПОМОЩЬЮ МНОГОСТВОЛЬНЫХ АРТИЛЛЕРИЙСКИХ СИСТЕМ
}

\author{
О. Г. Пенский, А. Г. Кузнецов
}

\begin{abstract}
В статье описан способ извлечения свай из грунта с помощью многоствольных артиллерийских откатных систем, основанный на жестком соединении извлекаемой сваи к откатным частям орудий и откате орудий во время выстрела. При описании извлечения свай из грунта рассмотрен трубчатый зерненый порох. Предложены математические модели для расчета динамики орудий во время одновременного выстрела из всех стволов и определения величины извлечения сваи из грунта. Описана методика проведения необходимых вычислений, основанная на поэтапном решении задачи Коши для первого и второго периодов выстрела. Численным экспериментом показана принципиальная возможность использования существующих одностовольных строительных артиллерийских систем для извлечения свай из грунта. Для модельных расчетов извлесения свай из грунта использовались параметры установки для застреливания анкеров и свай, внедренной в промышленность для обустройства нефтяных и газовых месторождений.
\end{abstract}

Ключевые слова: математические модели; строительство; артиллерийские орудия; динамика; проникание.

\section{Литература}

1. Способ извлечения строительных элементов из грунта с помощью многоствольных артиллерийских орудий: патент № 2017126845 Российская Федерация / О.Г. Пенский, Н.Н. Мазеина, Е.С. Шестаков. - 2017126845 (заявка на регистр. патента РФ на изобретение), дата приоритета 25.07.2017.

2. Маланин, В.В. Принципиальные схемы и математические модели строительных артиллерийских орудий / В.В. Маланин, Е.Н. Остапенко, О.Г. Пенский, А.В. Черников. - Пермь: Изд-во Перм. гос. ун-та, 2016.

3. Русяк, И.Г. Внутрикамерные гетерогенные процессы в ствольных системах И.Г. Русяк, В.М. Ушаков. - Екатеринбург: Изд-во УрО РАН, 2001.

4. Хоменко, Ю.П. Математическое моделирование внутрибаллистических процессов в ствольных системах / Ю.П. Хоменко, А.Н. Ищенко, В.З. Касимов. - Новосибирск: Изд-во СО РАН, 1999.

5. Чурбанов, Е.В. Внутренняя баллистика артиллерийского орудия / Е.В. Чурбанов. - М.: Воениздат, 1973.

6. Тихонов, А.Н. Дифференциальные уравнения / А.Н. Тихонов, А.Б. Васильева, А.Г. Свешников. - М.: Наука, 1980.

7. Бартоломей, А.А. Основы импульсной технологии устройства фундаментов / А.А. Бартоломей, В.Н. Григорьев, И.М. Омельча, О.Г. Пенский - Пермь: Изд-во ПГТУ, 2002. 
8. Программа расчета динамики извлечения свай из грунта с помощью многоствольных артиллерийских систем: свидетельство о государственной регистрации ПрЭВМ № 2017660043 / О.Г. Пенский. - 2017660043; зарегистр. 13.09.2017, Роспатент.

Пенский Олег Геннадъевич, доктор технических наук, доцент, кафедра механики и математического моделирования, Пермский государственный начиональный исследовательский университет (г. Пермь, Российская Федерация), оgрепsky@таil.ru.

Кузнецов Андрей Геннадъевич, кандидат технических наук, дочент, декан механико-математического факультета, Пермский государственный национальный исследовательский университет (г. Пермь, Российская Федерация), sp_9914@mail.ru.

Поступила в редакиию 25 января 2018 г. 